\title{
The economic burden of global blindness: a price too high!
}

The World Health Organisation defines blindness as a best corrected visual acuity of less than $3 / 60 .^{1}$ Using this definition it is estimated that there are currently 37.9 million blind people ( 1.4 million children $0-15$ years of age, and 36.5 million adults 15 years of age or greater) worldwide. ${ }^{2}$ Of this figure roughly $75 \%$ of all blind people live in the developing countries of Asia (21.4 million) and Africa ( $7 \cdot 1$ million), typically in rural areas with few or drastically underused eye care facilities. ${ }^{23}$ At least $50 \%$ to $70 \%$ of all cases of childhood blindness and $75 \%$ of adult blindness are either preventable or curable with currently available medical or surgical technology. ${ }^{3}$ Moreover, blindness prevention and treatment strategies are among the most cost effective of all known medical interventions. ${ }^{4}$

In economic terms, the cost of blindness depends not only on the cause and duration of the blinding disease, but also on the availability of family or alternative sources of economic assistance for blind individuals. Not surprisingly, therefore, children blinded during childhood or at birth incur a higher economic cost to their family members and society over their lifetime than adults blinded in later life. By the same token, the cost of blindness also depends upon how many blind people are economically productive, as well as on how many would enter economic activity if they were able to do so. While these variables are difficult to fully quantify on a global scale, a proxy measure of the cost of blindness may be had by estimating the loss of per capita gross national product (GNP) as a result of the loss of income from blind people over an individual's working life in each of the main global economic divisions. The guiding assumption of this approach is that blind people do not contribute to GNP when they are blind. While this is obviously not the case, exactly what proportion of per capita GNP may be attributed to blind people has not yet been reliability determined.

Table 1 summarises the population size, average GNP per capita, prevalence of blindness, number of blind, total working years lost due to blindness, and the loss of per capita and total GNP due to blindness for each of the main economic divisions. In calculating the per capita GNP lost due to blindness it is assumed that GNP would otherwise have grown by a rate of $3 \%$ per annum and that there were no new cases of blindness - that is, a best case scenario! It is further assumed that the total number of working years lost as a result of adult blindness ranges from 0-10 years, while for childhood blindness the figure ranges from 0-50 years. Lastly, it is assumed that $75 \%$ of adult blindness and $50 \%$ of childhood blindness is either curable or preventable.

The most striking feature of Table 1 is that the total GNP lost as a result of both childhood and adult blindness combined ranges from a low of US $\$ 167518$ million to a high of US $\$ 243938$ million. The total GNP of the UK, by contrast, is roughly US $\$ 1045674$ million. ${ }^{5}$ Viewed in other terms the total cost of global blindness is equal to roughly a sixth to a quarter of UK GNP. Clearly, the costs of blindness are unacceptably high, not only for blind people, but for society as a whole.

What can be done to reduce these costs? No single, or simple, solution exists. However, it is possible to organise the financial and personnel resources, both public and private, which are now available to combat blindness in far more effective ways. Sophisticated tools being developed in the emerging fields of 'ophthalmic services research' provide significant guidance in this context.

'Broadly defined, ophthalmic services research is an integrated discipline rooted in ophthalmology, epidemiology, economics and operations research' ... which ... 'attempts to use both clinical and nonclinical methods to ensure that the delivery of eye care services, be these surgical, or medical in a given region, are maximised to the fullest possible extent. ${ }^{, 6}$

Table 1 The cost of global blindness

\begin{tabular}{|c|c|c|c|c|c|c|c|c|}
\hline $\begin{array}{l}\text { Global } \\
\text { economic } \\
\text { division (a) }\end{array}$ & $\begin{array}{l}\text { Population } \\
\text { (millions) } \\
1993 \text { (a) }\end{array}$ & $\begin{array}{l}\text { GNP per } \\
\text { capita } \\
\text { (OSS) } \\
1993 \text { (a) }\end{array}$ & $\begin{array}{l}\text { Prevalence of } \\
\text { blindness (\%) } \\
\text { (b) }\end{array}$ & $\begin{array}{l}\text { Number of blind } \\
\text { people (millions) } \\
\text { (b) }\end{array}$ & $\begin{array}{l}\text { Total } \\
\text { working } \\
\text { years lost } \\
\text { due to } \\
\text { blindness } \\
\text { (c) }\end{array}$ & $\begin{array}{l}\text { GNP per capita } \\
\text { lost due to blindness } \\
\text { (growth rate=3\%) } \\
\text { OS\$ } 1993 \text { (d) }\end{array}$ & $\begin{array}{l}\text { Total GNP lost } \\
\text { due to blindness } \\
\text { (growth rate= } 3 \% \text { ) } \\
\text { OS\$ (millions) } \\
1993 \text { (e) }\end{array}$ & $\begin{array}{l}\text { Total GNP lost } \\
\text { due preventable } \\
\text { or curable } \\
\text { blindness (growth } \\
\text { rate }=3 \% \text { US } \$ \\
\text { millions } 1993(f)\end{array}$ \\
\hline $\begin{array}{l}\text { Low income } \\
\text { economies }\end{array}$ & 3092 & 380 & $0 \cdot 8$ & $\begin{array}{l}\text { Adults } 24.5 \\
\text { Children } 0.9\end{array}$ & $\begin{array}{l}0-10 \\
0-50\end{array}$ & $\begin{array}{l}380-511 \\
380-1666\end{array}$ & $\begin{array}{c}9310-12520 \\
342-1499\end{array}$ & $\begin{array}{c}6983-9375 \\
171-750\end{array}$ \\
\hline $\begin{array}{l}\text { Middle income } \\
\text { economies }\end{array}$ & 1596 & 2480 & 0.5 & $\begin{array}{l}\text { Adults } 9 \cdot 5 \\
\text { Children } 0.3\end{array}$ & $\begin{array}{l}0-10 \\
0-50\end{array}$ & $\begin{array}{l}2480-3333 \\
2480-10872\end{array}$ & $\begin{array}{c}23560-31664 \\
744-3262\end{array}$ & $\begin{array}{c}17670-23748 \\
372-1631\end{array}$ \\
\hline $\begin{array}{l}\text { High income } \\
\text { economies }\end{array}$ & 812 & 23090 & $0 \cdot 3$ & $\begin{array}{l}\text { Adults } 2 \cdot 5 \\
\text { Children } 0 \cdot 2\end{array}$ & $\begin{array}{l}0-10 \\
0-50\end{array}$ & $\begin{array}{l}23090-31031 \\
23090-101224\end{array}$ & $\begin{array}{r}57725-77578 \\
4618-20245\end{array}$ & $\begin{array}{r}43294-58184 \\
2309-10122\end{array}$ \\
\hline World total & 5500 & 4420 & $0 \cdot 7$ & $\begin{array}{l}\text { Adults } 36.5 \\
\text { Children } 1.4\end{array}$ & $\begin{array}{l}0-10 \\
0-50\end{array}$ & $\begin{array}{l}4420-5940 \\
4420-19377\end{array}$ & $\begin{array}{c}161330-216810 \\
6188-27128\end{array}$ & $\begin{array}{c}120998-162608 \\
3094-13564\end{array}$ \\
\hline
\end{tabular}

aData taken from the World Development Report 1995. ${ }^{5}$

bData taken from Thylefors $\mathrm{et}$ al. ${ }^{2}$

This represents an average number of working years lost due to blindness for all causes and the actual number of years may be lower.

This represents an average number of working years lost due to blindness for all causes and the actual number of year

e Given by GNP per capita $\times(1 \cdot 03)^{0-10}$ for adult blindness and GNP per capita $\times(1 \cdot 03)^{0-50}$ for childhood blindness.

fThis column is obtained by multiplying column (e) by 0.75 the total cost of adult blindness and by 0.5 the total cost of childhood blindness. 
Advances in data collection, organisation, and distribution have made it possible to significantly reduce duplication of services and to reallocate resources to areas or specific activities where these may be of the greatest economic and social benefit.

In a parallel fashion, sequencing allocation and routing algorithms, queuing models and decision analyses have been developed to a high standard in recent years by operations researchers. ${ }^{7}$ The results of their work are now being applied to significant competitive advantage by the management of firms, both large and (with the ever increasing use of personal computers), small worldwide. 'Just in time inventory' (JIT-I) delivery systems, now common, have resulted in huge cost savings and higher per unit profits for many retail and manufacturing firms in recent years. ${ }^{8}$ This is one simple example of the practical application of operations research techniques in the commercial world.

If the private sector can, so rapidly, take advantage of the fruits of this research why can't the public and 'parapublic' sectors follow its lead? No doubt they can! Moreover, if the direct and indirect costs of global blindness are to be significantly reduced, they must! It is feasible today that a system similar to the JIT-I models of the commercial world could be developed so as to better allocate scarce ophthalmic resources to those areas where these might meet the greatest need at the lowest per unit cost in the most effective way possible. This presents a tremendous challenge. But tools to do the job are at hand. These simply need to be applied.

Preventive Ophthalmology and Epidemiology Unit, ANDREW F SMITH

Department of Ophthalmology,

Dalhousie University, 1335 Queen Street,

Halifax, Nova Scotia, Canada B3J 2H6

Faculty of Management, McGill University,

J GRAHAM SMITH

1001 Sherbrooke Street West, Montreal,

Quebec, Canada H3A 1G5

1 World Health Organisation. Guidelines for programmes for the prevention of blindness. WHO: Geneva 1979.

2 Thylefors B, Negrel AD, Pararajasegaram R, Dadzie KY. Global data on blindness. Bull World Hlth Org 1995; 73: 115-21.

3 Foster A. World-wide blindness, increasing but avoidable! Sem Ophthalmol 1993; 8: 166-70.

4 Sommer A. Toward affordable, sustainable eye care. Int Ophthalmol 1995; 18: 287-92.

5 World Development Report 1995. Workers in an integrating world. New York: Oxford University Press, 1995.

6 Smith AF. Ophthalmic services research: towards increasing the role of economic and operations research methods in the delivery of eye care services. Br f Ophthalmol 1995; 79: 515-6.

7 Srivastava HM, Kashyap BR. Special functions in queuing theory: and related stochatic processes. New York: Academic Press, 1982.

8 Zipkin PH. Does manufacturing need a JIT revolution? Harvard Business Review 1991; Jan-Feb: 40-50. 